\title{
THE
}

$12-2004$

\section{Mobility and Markets: Emerging Outlines of M-commerce}

Ruby Roy Dholakia

University of Rhode Island, ruby@uri.edu

Nikhilesh Dholakia

University of Rhode Island, nik@uri.edu

Follow this and additional works at: https://digitalcommons.uri.edu/cba_facpubs

Part of the E-Commerce Commons, and the Marketing Commons

Terms of Use

All rights reserved under copyright.

\section{Citation/Publisher Attribution}

Dholakia, Ruby Roy, and Nikhilesh Dholakia. "Mobility and Markets: Emerging Outlines of M-Commerce." Journal of Business Research, vol. 57, no. 12 (December 2004): 1391-1396.

DOI: 10.1016/S0148-2963(02)00427-7

This Article is brought to you for free and open access by the College of Business at DigitalCommons@URI. It has been accepted for inclusion in College of Business Faculty Publications by an authorized administrator of DigitalCommons@URI.For more information, please contact digitalcommons-group@uri.edu. 


\title{
Mobility and Markets: Emerging Outlines of M-Commerce
}

\author{
Ruby Roy Dholakia and Nikhilesh Dholakia
}

\author{
College of Business Administration \\ University of Rhode Island \\ 210 Flagg Road \\ Kingston, RI 02881 (USA)
}

Tel: 401-874-4390, Fax: 401-874-4312, uby@uri.edu \& hik@uri.edu 


\title{
Mobility and Markets: Emerging Outlines of M-Commerce
}

\author{
$\underline{\text { Abstract }}$ \\ Mobile commerce - or m-commerce - is characterized by the emerging class of location- \\ based commercial services delivered by a variety of handheld terminals such as mobile phones \\ and palmtop devices. At COTIM-2001, an international conference in Germany, academic \\ researchers and business practitioners shared their experiences and frameworks about m- \\ commerce. Selected authors from COTIM-2001 were invited to further develop their conference \\ contributions for this Special Issue. This paper discusses the preconditions that led to the \\ emergence of m-commerce, the main dimensions of m-commerce that distinguish it from e- \\ commerce, and the key arguments from the contributions on m-commerce in this special issue of \\ the Journal of Business Research.
}




\section{Mobility and Markets: Emerging Outlines of M-Commerce}

The rapid diffusion of mobile telephones across the globe in the last two decades of the twentieth century laid the foundation for a new type of technology-aided commerce. Going beyond the computer-mediated electronic commerce or e-commerce ${ }^{\square}$ of the 1990 s, this new type of mobile commerce - or m-commerce - is characterized by novel, location-based services delivered by a variety of handheld terminals. By 2000, Japan's NTT DoCoMo had already established a huge network of m-commerce service providers and users that relied on that company's iMode platform (Bradley and Sandoval 2002). Towards the end of 2002, the next (third) generation of mobile telecommunication networks was being deployed in many global locations, paving the way for many new m-commerce products and services.

As a portal into the contents of this special issue, this paper discusses the:

- Preconditions that led to the emergence of m-commerce

- Main dimensions of m-commerce that connect it, yet set it apart from, e-commerce

- Key arguments and contributions of the papers related to m-commerce in this special issue of the Journal of Business Research.

\section{PRECONDITIONS TO M-COMMERCE}

Just as the Internet and user-friendly web browsers provided the preconditions for the take-off of e-commerce, mobile telephones that are data-ready and connected to digital communication networks provide the preconditions for m-commerce. In recent years, other handheld mobile devices such as Personal Digital Assistants (PDAs) and enhanced alphanumeric

\footnotetext{
${ }^{1}$ To simplify usage, we will employ the term "e-commerce" for electronic commerce transactions carried out via fixed, wired terminals and the term "m-commerce" for electronic commerce transactions carried out via mobile, wireless terminals. In the larger sense, both are variations of electronic transactions, but using the prefix "e" for fixed/wired and " $m$ " for mobile makes it easier to contrast these two types of electronic transactions.
} 
communicators have supplemented mobile telephones, thus expanding the devices available for m-commerce transactions.

Across the globe, mobile communications access does not correlate perfectly with per capita income or computerized Internet access. In Table 1, we have arranged a select group of North American, European Union, and Asian countries according to descending order of mobile telephony access. As can be seen from the rank orderings, the countries with the highest mobile communications access are not always the richest or the most Internet-using countries. While the correlation between Internet use and GNP is high and significant (Spearman rho=.51, $\mathrm{p}<.01$ ), the correlations between mobile access and GNP or mobile access and Internet access fail to reach statistical significance. Countries such as Australia and Canada - strong adopters of the Internet - are positioned relatively low in terms of mobile phone adoption. United States, in particular, which is also a pioneer in e-commerce, ranks quite low in terms of mobile access. This means that many of the initial applications of m-commerce are likely to emerge in Europe and Asia, although technology derived from U.S. sources could power many of these applications. The context and the authorship of the papers in this special issue reflect this global character of m-commerce. Views and analyses originating from Europe, Asia, and North America are represented in the special issue.

\section{CHARACTERIZING M-COMMERCE APPLICATIONS AND SERVICES}

A mobile network has many advantages over fixed voice or fixed PC-based data networks. These include the lower levels of investment for building infrastructure, lower costs

of developing and provisioning services, and lower costs and greater ease of using services. Even in regions with difficult geography or poor economic conditions, mobile networks can be designed and implemented in far quicker and cost-efficient ways than fixed networks. Mobile 
networks are also more scaleable - the network size can be expanded quickly as demand rises. As a result, mobile phones have lower fixed costs than fixed phones, the payback period for the investment in mobile networks is relatively short, and mobile networks can break even with a much smaller subscriber base.

With pre-payment a frequent option, mobile networks are able to reach users with limited resources - users who do not have established credit and billing histories. Of new mobile communications users in 1999, 70\% in Thailand and 100\% in Malaysia were prepaid users (The Economist 1999). In certain cultures where sharing of tools and resources are common and valued, sharing of mobile handsets is easier than sharing of fixed phone or fixed data networks (Lopez 2000). Such sharing makes the potential m-commerce customer base far larger than the nominal subscriber base. In Bangladesh, for instance, 70 people on an average share the use of a single village-level mobile phone (World Bank 2001). Micro-payments are also much more easily managed with mobile networks, thereby facilitating frequent and small transactions and allowing purchases of a greater assortment of goods and services.

The emergent m-commerce space, as distinct from the established e-commerce space, has a number of differentiating characteristics. Some of these differentiating characteristics of the mcommerce space are shown in Figure 1. In essence, m-commerce opens up opportunities for reaching customers at multiple (targeted) locations, for configuring services and offerings in novel (pinpointed) ways, and enabling new (empowering) types of shopping and service consumption experiences.

A critical determinant of the success of m-commerce strategies is how well the $\mathrm{m}$ commerce providers understand the variety of roles that people could play in the busy lifestyles and work styles of today. Table 2 depicts the complex combinations that result from a person's 
location (work, home, other), his or her prescribed or self-ascribed role (professional and on duty, or private and off duty), and the stance (in terms of time commitment and busyness).

It is clear from Table 2 that the primary benefit sought from m-commerce technologies is usually dependent on the stance, in terms of time commitment and busyness. The specific nature of the desired benefit would, however, also depend on the location of the user and the role s/he is in. Consider two settings where an individual is away from office or home - the location is "other" - and is waiting for a bus. In the first instance, the person is on a job-related trip and is waiting for a bus to the airport. In such a setting, the person is much more likely to use the "time on hand" for a productivity-oriented application (adjusting the appointment calendar, reorganizing slides in a presentation) than for an entertainment application. The same individual, while waiting for a tour bus at a vacation destination, is likely to turn to the m-device for entertainment.

In designing and evaluating $\mathrm{m}$-commerce applications - in addition to the typical demand, cost, and competitive analyses - the m-commerce provider must also study the locationstance-role dynamics (such as the ones shown in Table 2) in fine-grained detail. Two papers in this Special Issue specifically address the problems of designing successful m-commerce applications based on situation-dependencies. With network-enabled elements and geographical positioning, it is possible for the m-commerce provider to make a first-cut surmising of the location-stance-role setting of the user. This can be refined further by dynamically tracking the user's mobile transactions and drawing inferences from these - what did the user do in the last few m-transactions? Finally, user's own inputs such as pre-stated preferences, user-initiated requests, or responses to queries posed by the m-commerce provider can be used to refine the location-stance-role setting of the user. By such analysis, the m-commerce provider can zero-in 
on user needs and desires in ways that are simply not feasible under traditional e-commerce. Of course, in all such transactions, issues of privacy and security are paramount. Users are likely to shun m-commerce providers who are perceived as providing inadequate safeguards in terms of privacy and security of transactions and of users' stored profiles.

\section{CONTRIBUTIONS IN THIS SPECIAL ISSUE}

In 2001, issues of m-commerce were discussed at the Fourth International Conference on Telecommunications and Information Markets (COTIM) in Karlsruhe, Germany. The "dotcom" shakeout of 1999-2000 had put e-commerce and m-commerce on the defensive. While academic researchers and business practitioners recognized that the electronic marketspaces were here to stay, there was a great deal of uncertainty regarding business approaches that were likely to succeed in the new environments.

Researchers from several countries convened for three days to discuss various issues regarding e-commerce and m-commerce. Speakers from successful businesses - both small and large - shared their experiences and their aspirations.

Invitations were extended to a few selected authors to further develop their conference paper for this Special Issue. These selections were based on the initial review of submitted manuscripts, presentations at the conference itself, and discussions with the authors. The papers selected for this special issue are organized as follows:

Lehrer

Worter \& Bullingen

Lupp \& Gerstheimer
National Lead Markets for 3G Mobile Networks: A Framework

Development Strategies, Strategic Perspectives and Applications in Mobile Commerce

Designing 3G Applications: A Framework to Translate Needs into Technology 
Figge

Frank, Heitmann, Leibold \& Stroborn

Chou, Lee \& Chung
Developing Situation-Dependent M-Commerce Applications

Internet Payments in Germany: Classificatory Framework and Empirical Evidence

Understanding Payment Systems for M-Commerce through Analytical Hierarchy Process

Table 1 has shown the differences in mobile access across the globe. A large part of these differences is caused by national level policies that influence the development of the mobile sector and the services offered to various customer publics. Governments' willingness to open the market for competition and invest in mobile sector has affected the diffusion of mobile devices directly through the prices charged as well as indirectly through the content made available. In his paper "National Lead Markets and the Design Competition for 3G Network Applications" Lehrer argues that while the real design competition for m-commerce applications has scarcely begun, it is likely to entail a distinctly national dimension even within the increasingly integrated European Union (EU). He further argues that Germany and UK, while laggards in mobile telephony within EU, are likely to be the leaders in m-commerce applications because of the size their national markets. He believes the high prices of $3 \mathrm{G}$ licenses in Germany and UK offer some evidence in support of the "national lead market" thesis he is proposing.

The positive impact of national level policies can only be realized if business firms are stimulated to take the risks and invest in the new networks and service applications. Based on structured expert interviews, Buellingen and Woerter attempt to address the various factors that are likely to contribute to the success of m-commerce. Because Internet access is likely to be greater via mobile phones than via fixed network devices by the year 2003, the authors report mobile operators are better positioned to play the "gatekeeper role" in this expansion of the value chain. This role becomes even more critical - for purposes of customer relationship 
management - as aggregation of services received from many different service providers (devices, data packets, information services) becomes essential.

Whether it is done by mobile operators or by other players in the supply chain such as handset manufacturers, designing successful $3 \mathrm{G}$ applications for $\mathrm{m}$-commerce requires building on user needs. So argue Lupp and Gerstheimer in their paper "Needs versus Technology - The Challenge to Design 3G Applications." While this appears to be a simple extension of customeroriented product development strategy, it is not a common experience in this technology-focused industry. The authors describe the "maieutic" - the term refers to the Socratic method that induces a respondent to formulate latent concepts through a dialectic or logical sequence of questions - user interaction process that examines the connections between user needs and products. Lupp and Gerstheimer provide the example of a potential new application "BusinessCall" that takes advantage of location and time specific characteristics of a communication.

The importance of situation dependency (see Table 2) is explored in depth in Figge's paper "Situation Dependent Services - A Challenge for Mobile Network Operators". Spatial, personal, and temporal characteristics are unique attributes of mobile communications that must be incorporated into an m-service provider's service design. The determination of the situation identity, position, and time - becomes critical for computation of the context in which m-services are provided. Figge believes that the "Situation Provider" can act as the general intermediary for m-commerce and - like Buellingen and Woerter - feels that the Mobile Network Operator is best suited to occupy this role.

It is likely that several key players will juggle for the gatekeeping position in the emerging m-commerce contexts. One of the drivers of this position will be customer willingness 
to pay for m-services as well as the preferred mode of payment. Chou, Lee and Chung address this issue in their paper "Understanding Payment Systems for M-Commerce through Analytical Hierarchy Process". Several application developers have recognized the key importance of payments for e- and m-commerce. While several forms of electronic cash - such as Digicash, Cybercash, First Virtual - were invented early on in the development of e-commerce, none of these early applications took off in a big way. Instead, credit cards are the most common method of payment for transactions over the Internet today. The authors examine the appropriateness of various payment methods for the e-business environment. Specifically they look at four epayment systems in terms of technological, economic, and social factors. They use the analytical hierarchy process method to evaluate the four methods based on an "expert poll" of Internet business executives and scholars in Taiwan. Based on this method, the stored-value card - a form of prepaid card - emerges as the superior e-payment instrument rather than the credit card (in use most today) or the telecommunications bill (which would favor the mobile network operator).

Stroborn, Frank, Heitmann, and Leibold also address the issue of payments in their paper "Internet Payments in Germany: Classificatory Framework and Empirical Evidence". Their perspective, however, is from the consumer side - they attempt to explain consumer acceptance of payment systems. After noting that there are distinct differences in payment habits across various European countries, they specifically focus on Germany. Like Lupp and Gerstheimer, they note that new payment systems have been high on technical sophistication and low on customer orientation. Based on a panel of German consumers, they note the consumer preference for conventional payment systems such as credit cards. This is because low costs, easy handling, security and guarantees are important. 


\section{CONCLUDING REMARKS}

Like e-commerce that preceded it, the important question about m-commerce is not about whether it will happen or not. The key questions are about the forms that m-commerce will take, the policy and competitive conditions under which m-commerce would thrive, and the potential responses of users to various m-commerce formats.

Papers in this special issue focus on these details - the forces and mechanisms that would shape the character of emergent m-commerce. By doing so, the papers in this special issue set the stage for practitioners who want to develop m-commerce ventures with strong market appeal. These papers also set an implicit research agenda - an agenda that requires cooperation across business and technical disciplines in terms of understanding competitive processes and user contexts. We hope the work presented here will help advance both the state of practice and the state of research pertaining to m-commerce.

\section{REFERENCES}

Bradley, Stephen P. and Matthew Sandoval (2002), "Case Study: NTT DoCoMo - The Future of the Wireless Internet?" Journal of Interactive Marketing, 16 (Spring), 80-96.

Samuelsson, Mats and Nikhilesh Dholakia (2003), "Assessing the Market Potential of NetworkEnabled 3G M-Business Services," in Wireless Communications and Mobile Commerce, Shi Nansi (ed.), Singapore \& Hershey PA: Idea Group Publishing (forthcoming).

World Bank (2001) "Linking Rural Bangladesh Through Cellular Phones: IFC invests in Grameenphone," http://wbln1018.worldbank.org/sar/sa.nsf/2991b676f98842f0852567d7005d2cba/71044b08a $15612588525686 \mathrm{~d} 0060040 \mathrm{~b}$ ?OpenDocument 
Table 1: Mobile Penetration, Per Capita GNP, and Internet Use

\begin{tabular}{|l|l|l|l|l|l|l|}
\hline Country & $\begin{array}{l}\text { Mobile } \\
\text { phones } \\
\text { per 1000 } \\
(1999)\end{array}$ & $\begin{array}{l}\text { Rank } \\
\text { Order }\end{array}$ & $\begin{array}{l}\text { GNP per } \\
\text { capita in } \\
\text { US\$ } \\
(2000)\end{array}$ & $\begin{array}{l}\text { Rank } \\
\text { Order }\end{array}$ & $\begin{array}{l}\text { Internet } \\
\text { users per } \\
1000 \text { people } \\
(1999)\end{array}$ & $\begin{array}{l}\text { Rank } \\
\text { Order }\end{array}$ \\
\hline Hong Kong & 726 & 1 & 25950 & 6 & 205 & 14 \\
\hline Finland & 667 & 2 & 24900 & 10 & 404 & 2 \\
\hline Sweden & 578 & 3 & 26780 & 5 & 445 & 1 \\
\hline Italy & 528 & 4 & 20010 & 18 & 158 & 18 \\
\hline Taiwan & 521 & 5 & 16100 & 19 & 216 & 11 \\
\hline Austria & 519 & 6 & 25220 & 7 & 203 & 15 \\
\hline South Korea & 504 & 7 & 8490 & 24 & 213 & 12 \\
\hline Denmark & 499 & 8 & 32020 & 4 & 394 & 3 \\
\hline Singapore & 475 & 9 & 24740 & 11 & 289 & 6 \\
\hline Portugal & 468 & 10 & 11060 & 23 & 80 & 24 \\
\hline Japan & 449 & 11 & 34210 & 3 & 162 & 17 \\
\hline Netherlands & 435 & 12 & 25140 & 8 & 258 & 8 \\
\hline Switzerland & 420 & 13 & 38120 & 1 & 234 & 10 \\
\hline UK & 408 & 14 & 24500 & 13 & 255 & 9 \\
\hline Ireland & 378 & 15 & 22960 & 15 & 132 & 21 \\
\hline France & 364 & 16 & 23670 & 14 & 121 & 22 \\
\hline Australia & 344 & 17 & 20530 & 17 & 261 & 7 \\
\hline Belgium & 315 & 18 & 24630 & 12 & 180 & 16 \\
\hline Spain & 312 & 19 & 14960 & 20 & 91 & 23 \\
\hline Greece & 311 & 21 & 11960 & 22 & 140 & 20 \\
\hline USA & 312 & 19 & 34260 & 2 & 351 & 5 \\
\hline Germany & 286 & 22 & 25050 & 9 & 149 & 19 \\
\hline New Zealand & 230 & 23 & 13080 & 21 & 209 & 25 \\
\hline Canada & 230 & 23 & 21050 & 16 & 369 & 14 \\
\hline Argentina & 121 & 25 & 7440 & 25 & 14 & \\
\hline & Rank Corretations: & \\
\hline
\end{tabular}

Rank Correlations: Spearman Rho (significance level): Mobile with GNP = .32 (.11); Mobile with Internet $=.34(.09)$; GNP with Internet $=.51(.01)$

Sources: International Marketing Data and Statistics, European Marketing Data and Statistics, The World Bank, http://www.3gnewsroom.com/country/index.shtml 
Figure 1: Key Dimensions of the Emergent M-Business Space

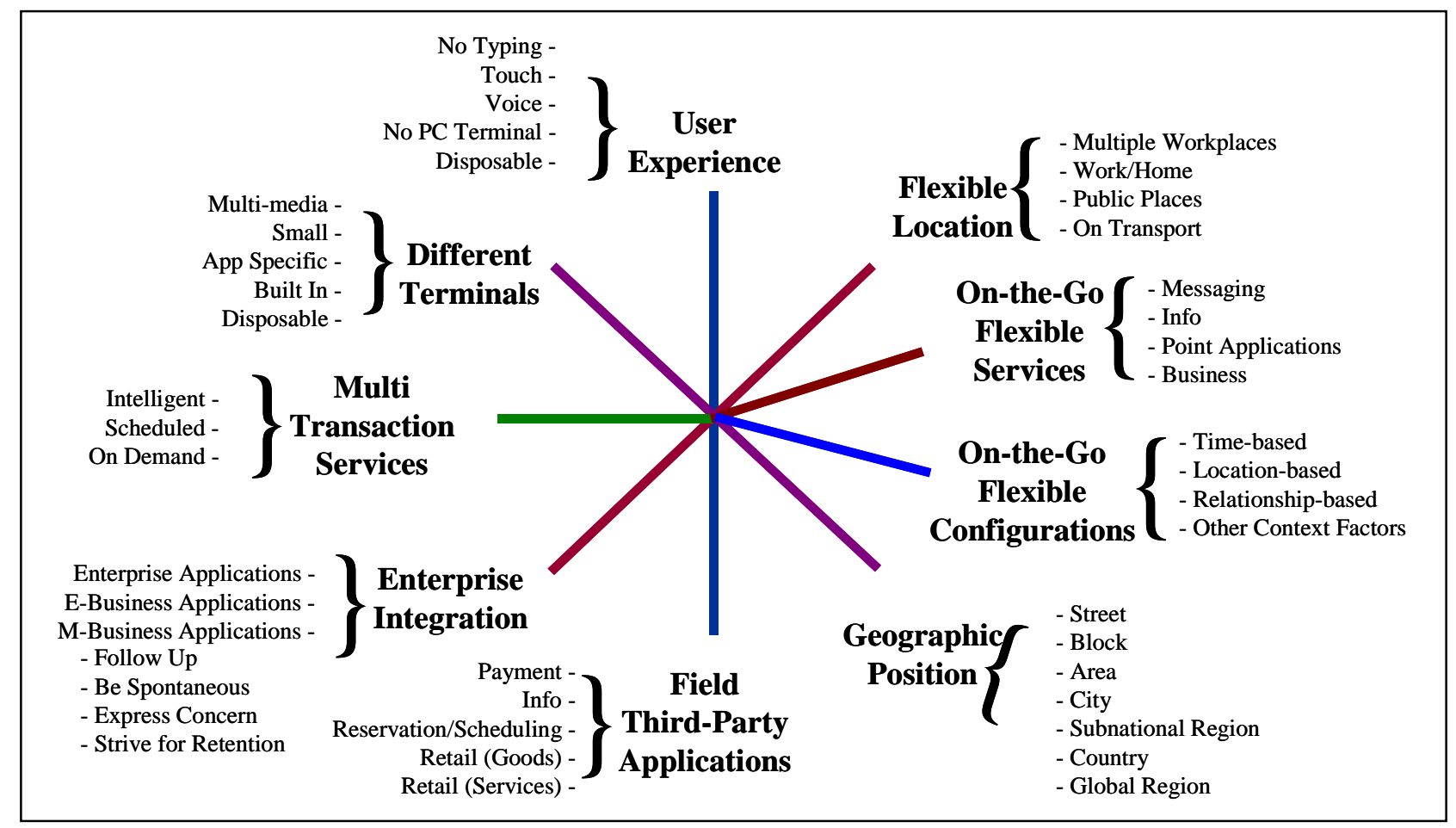

Source: Adapted from Samuelsson and Dholakia (2003) 
Table 2: Complex Interactions of Location, Roles, and Stances

(Cell entries indicate primary benefit sought in that setting)

\begin{tabular}{|c|c|c|c|}
\hline \multirow[b]{2}{*}{ Location } & \multirow[b]{2}{*}{ Stance } & \multicolumn{2}{|c|}{ Role } \\
\hline & & $\begin{array}{l}\text { Professional } \\
\text { (on duty) }\end{array}$ & $\begin{array}{l}\text { Private } \\
\text { (off duty) }\end{array}$ \\
\hline \multirow[t]{2}{*}{ Work } & Busy & Productivity & \\
\hline & Time on hand, Waiting & $\begin{array}{l}\text { Productivity or } \\
\text { Entertainment }\end{array}$ & $\begin{array}{c}\text { Entertainment or } \\
\text { Productivity }\end{array}$ \\
\hline \multirow[t]{2}{*}{ Home } & Busy & \multicolumn{2}{|c|}{ Convenience } \\
\hline & Open to diversion & \multicolumn{2}{|c|}{ Entertainment } \\
\hline \multirow[t]{2}{*}{ Other } & Busy & \multicolumn{2}{|c|}{ Efficiency } \\
\hline & Time on hand, Waiting & $\begin{array}{c}\text { Efficiency or } \\
\text { Entertainment }\end{array}$ & $\begin{array}{c}\text { Entertainment or } \\
\text { Convenience or } \\
\text { Efficiency }\end{array}$ \\
\hline
\end{tabular}

